\title{
Analysis of runoff characteristics and contribution rate in Xiying River Basin in the Eastern Qilian Mountains
}

\author{
Lei Feng $^{1}$, Dong Yang ${ }^{1 *}$ and Yueyue Huang ${ }^{1}$ \\ ${ }^{1}$ College of Geography and Environmental Science, Northwest Normal University, Lanzhou, Gansu, 730070, Chin
}

\begin{abstract}
The impact of climate change on the basin is extensive and long-lasting, which will have a profound impact on the natural ecosystems, water resources, agriculture, and human production and life throughout the basin. An in-depth understanding of the impacts of climate change on watersheds and quantitative assessments will help to scientifically plan and manage water resources and protect the integrity of natural ecosystems. In this paper, temperature, precipitation and potential evapotranspiration data were used to analyze the response of Xiying River runoff to climatic factors in the Qilian Mountains by sliding correlation and wavelet analysis. M-K test and cumulative anomaly (CA) were used to analyze the climatic factors and runoff in the basin and use the pettitt method to test. Finally, the cumulative rate slope change rate comparison method was used to analyze the change of precipitation, potential evapotranspiration and snow-melt water contribution to runoff in this area. The results showed that temperature, precipitation and potential evapotranspiration had obvious mutations from 1961 to 2012 in this region. Compared with temperature and potential evapotranspiration, the precipitation showed greater impact on runoff. In addition, the contribution rate of ice and snow melt water to runoff was relatively larger in 1990 - 2002 compared to 1961-1989, followed by precipitation and evapotranspiration; the increase of the precipitation contribution rate became the main factor to runoff, followed by ice and snow melting and evapotranspiration compared to $1990-2002$ in 2003-2017.
\end{abstract}

\section{Introduction}

Global climate change has a profound impact on the terrestrial hydrological cycle, and the rate of climatic factors change was accelerating. Many scholars have begun to pay attention to its impact on the water cycle mechanism [1]. In the context of global warming, the average daily precipitation and extreme daily precipitation were continuously increased in many regions, which provided strong supports for the view that the water cycle was increasing [2-3]. The IPCC's first assessment report that the global warming in the past 100 years was estimated to be $0.45{ }^{\circ} \mathrm{C}$, which rose to $0.85 \sim 0.89{ }^{\circ} \mathrm{C}$ in the fifth assessment report, and the global warming trend was obvious [4-5]. The impact of climate change on river basins was mainly reflected in changes of watershed area and runoff [6-7]. As an important part of the water cycle process in the basin, runoff was sensitive to climate change [8]. Chen et al [9] found that surface runoff in Canada showed an increasing trend in 2081-2100 through quantifying the prediction of the climate change effects on runoff, while Radchenko [10] found the summer runoff will reduced but the winter and spring runoff will increased from 2071 to 2100 in the Fergana Gorge in Central Asia through the HBV-light model, compared with 1971-2000. The study of predicted the change in the Amazon basin area found that the increase in temperature and precipitation would cause same change in the flood area in one third of the basin, especially, the precipitation time may increase by about 3 months in the eastern part of the Amazon [11]. Therefore, although the global average precipitation shows an increasing trend, the trend of different regional runoffs is different considering the regional temperature, evapotranspiration and other factors, [6].

The runoff changes was deeply affected by factors such as temperature, precipitation, evapotranspiration, ice and snow melt water, and changes in land use types [12-13]. The study of climate and human factors for global ocean emissions had found that the flow trends of many rivers was mainly reflect the change of precipitation due to the influence of atmospheric-ocean circulation, showing that the runoff in mid-latitude regions were reduced and increased at high latitudes [14]. A study in different regions of the Nile River Basin found that a $10 \%$ increase in precipitation would increase runoff in the tropical regions of the basin, while the arid regions had opposite changes [15]. In the Great Plains of North America, the contribution rate of spring rainfall to rainfall runoff increased by $51 \%$, and the snow and ice melt water to runoff decreased by $59 \%$ during the same period [16]. But in the observation of glacial runoff had found that glacial runoff will show a steady decline in the context of global climate change in high latitudes [17]. In the climate-ridden Central Asia region, climate warming would lead to an increase in the annual total

$\overline{{ }^{*} \text { Corresponding author's e-mail: yangdong@nwnu.edu.cn }}$ 
evapotranspiration, which will bring greater changes to the form of river recharge in the area. And the overall runoff of the river would decrease, and the recharge time would be advanced [18]. A study on the runoff variation of rivers with different supply sources found that temperature rise was the main factor of river runoff change in this region and human activities have gradually became an important factor causing river runoff changes in northwestern China [19].

More and more studies have shown that in the context of global warming climate, the rate of temperature increase would rise with the altitude adding, and the temperature change of alpine climate was more significant than that of low altitude [20]. Elevated dependence warming (EDW) was obvious in the Qinghai-Tibet Plateau, so the region had become one of the most sensitive regions to respond to global climate change [21-22]. Located in the northeastern part of the Qinghai-Tibet Plateau, Qilian Mountain is an ecologically fragile cold and arid zone and a monsoonaffected marginal zone. It is an important ecological barrier in northwestern China [23]. According to the research on runoff variation in Qilian Mountainous Area, the runoff change in this area was less affected by human factors, and the climate had greater impact [24]. In addition, there was a big difference in the trend of runoff change between the eastern and western regions and the central region [25]. Furthermore, the study on runoff variation in Qilian Mountain area was mainly focused on the overall analysis of the three main domains of Heihe River, Shule River and Shiyang River, but the microlevel analysis of river source areas involves less [26-27]. Therefore, in this paper, we used the cumulative slope change rate comparison method proposed by Wang Suiji [28] to quantitatively analyze the characteristics of the Xiying River Basin runoff variation in the climate change background, which is the maximum primary tributary of the Shiyang River Basin. This method was widely used in quantitative research on runoff variation in arid and semi-arid areas of Northwest China [29]. The aim of this paper was to solving the following three problems: 1) Understand the climate and runoff variation characteristics of the river basin. 2) Confirmed the main factors causing the change of runoff in different time periods; 3) Quantitative analyzed the contribution rate of various factors causing changes in runoff at different time periods.

\section{Formatting the title, authors and affiliations}

\subsection{Study Area}

Xiying River is located in the northeastern part of the Qilian Mountains in northwestern China (101 $39^{\prime}-$ $102^{\circ} 24^{\prime} \mathrm{E}$ and $\left.37^{\circ} 28^{\prime}-38^{\circ} 2^{\prime} \mathrm{N}\right)$. It is the largest primary tributary of the Shiyang River Basin, one of the three inland river basins in the Hexi Corridor, originating from the LengLongling Peak in the eastern section of the Qilian Mountains, flows southwest to the northeast and flows into the Xiying Reservoir after exiting the mountain (Figure 1). The basin is located in a temperate continental arid climate zone. The climatic characteristics are cold and rare precipitation in winter, many high-temperature precipitations in summer in this area. The altitude is about $1873-4911 \mathrm{~m}$, the drainage area are $1727.5 \mathrm{~km}^{2}$, and there has JiuTiaoling hydrological stations $\left(102^{\circ} 3^{\prime} \mathrm{E}\right.$ and $37^{\circ} 52$ 'N). During the period of 1961-2017, the average annual temperature was $-0.63{ }^{\circ} \mathrm{C}$, the annual precipitation was $489.13 \mathrm{~mm}$, and the runoff was $3.16 \times 10^{8} \mathrm{~m}^{3}$.

\subsection{Data Sets}

2.2.1 Meteorological Data. The meteorological data was come from the China Meteorological Data Sharing Service Network. The daily data includes daily average temperature, daily minimum temperature, daily maximum temperature, daily precipitation, sunshine hours, daily average relative humidity and daily average wind speed. Monthly data includes China's surface temperature monthly value of $0.5^{\circ} \times 0.5^{\circ}$ grid data set (V2.0) and China's ground precipitation monthly value of $0.5^{\circ} \times 0.5^{\circ}$ grid data set (V2.0), length of time was 1961-2017 year.

2.2.2 Runoff Data. The runoff data was derived from monthly measured runoff data from the JiuTiaoling Hydrological Station (Figure 1) in the Xiying River Basin provided by the Shiyang River Basin Authority. The length of time was $1961-2017$.

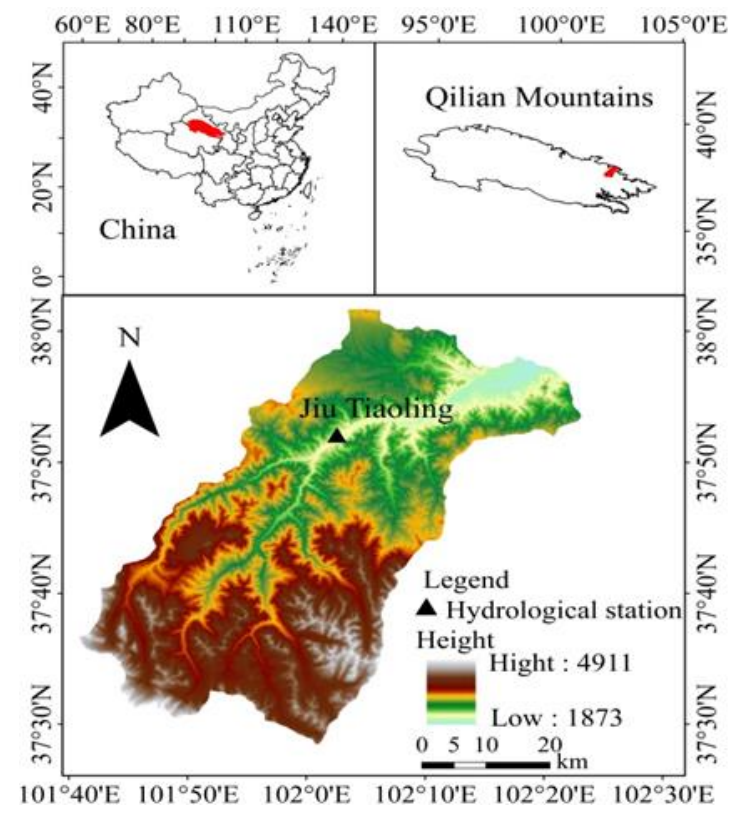

Figure 1. Overview of the study area.

\subsection{Methods}

2.3.1 Mutation analysis. The regression analysis and sliding mean method were used to analyze the trend of temperature precipitation and runoff in the Xiying River Basin, and the periodic characteristics of precipitation 
and runoff in the basin were analyzed by wavelet transform and wavelet variance test. Although the MannKendall mutation test has the advantage that the outliers have less interference to the results, the detection results may have drift and pseudo-mutation points [30-31], the results of the Mann-Kendall mutation test and cumulative anomaly (CA) mutation test for climatic factors and runoff were verified by the Pettitt test[32-33], in which the significance level of the M-K method and the Pettitt method was set to 0.05 , the critical value of M$\mathrm{K}$ is $\mathrm{U}= \pm 1.96$.

\subsubsection{Mann-Kendall mutation test:}

First, for the time series $\mathrm{X}$ (containing $\mathrm{n}$ samples), construct the order column:

$$
s_{k}=\sum_{i=1}^{k} r_{i} \quad(k=2,3, \ldots, \mathrm{n})
$$

In the formula

$$
r_{i}=\left\{\begin{array}{ll}
+1 & x_{i}>x_{j} \\
0 & \text { else }
\end{array} \quad(j=1,2, \ldots, i)\right.
$$

In the order column, $S_{k}$ indicates that the value of the $\mathrm{i}$-th time is greater than the value of $\mathrm{j}$ times, and the number of values is accumulated.

Define the statistic under the assumption that the time series is random:

$$
U F_{k}=\frac{\left[s_{k}-E\left(s_{k}\right)\right]}{\sqrt{\operatorname{Var}\left(s_{k}\right)}} \quad(k=1,2, \ldots, \mathrm{n})
$$

In the formula, $U F_{1}=0, E\left(s_{k}\right)$ and $\operatorname{Var}\left(s_{k}\right) s_{k}$ are the mean and variance of $S_{k}$, when $x_{1}, x_{2}, \ldots, x_{n}$ are independent of each other, according to their same continuous distribution, can be calculated The following formula:

$$
\begin{gathered}
E\left(s_{k}\right)=\frac{n(n+1)}{4} \quad(2 \leq k \leq \mathrm{n}) \\
\operatorname{Var}\left(s_{k}\right)=\frac{n(n-1)(2 n+5)}{72} \quad(2 \leq k \leq \mathrm{n})
\end{gathered}
$$

$U F_{k}$ represents a standard normal distribution, which is a statistic sequence calculated in the order of time series $\mathrm{X}\left(x_{1}, x_{2}, \ldots, x_{n}\right)$. Given the significance level $\alpha$, according to the normal distribution table, if $U F_{i}>U_{\alpha}$, it indicates that there is a significant trend change in the sequence. Repeat the above process in the reverse order of time series $\mathrm{X},\left(x_{n}, x_{n-1}, \ldots, x_{1}\right)$, and let $U B_{k}=U F_{k}(\mathrm{k}=\mathrm{n}, \mathrm{n}-1, \ldots, 1), U B_{1}=0$

\subsubsection{The Slope Changing Ratio of Cumulative} Quantity. The slope changing ratio of cumulative quantity (SCRCQ) was proposed by Wang Suiji et al to study the contribution rate of runoff variation in the HuangFuchuan watershed in 2012. The method overcomes the fitting defect of the original precipitationrunoff double accumulation curve in the inflection point year, and significantly improves the correlation of the fitting [28]. The principle was to divide the study period by accumulating the anomaly inflection point. It was assumed that the slope of the linear relationship of the cumulative precipitation before and after the mutation point is recorded as $\mathrm{K}_{\mathrm{Pa}}$ and $\mathrm{K}_{\mathrm{Pb}}$ (unit: $\mathrm{mm} \cdot \mathrm{a}^{-1}$ ), and the of change is the difference between the slope before and after the change and the slope before the change recorded as $\mathrm{S}_{\mathrm{P}}$; Similarly, the rate of change in runoff and evapotranspiration is recorded as $\mathrm{S}_{\mathrm{R}}$ and $\mathrm{S}_{\mathrm{ET}}$. The Xiying River Basin has a high altitude and low human activities, which has little impact on runoff. The runoff changes are mainly affected by natural factors such as precipitation, evapotranspiration and melting of snow and ice. According to the definition of the slope changing ratio of cumulative quantity:

Cumulative precipitation slope changing ratio $\left(S_{P}\right)$ is:

$$
S_{P}=\frac{K_{P b}-K_{P a}}{K_{P a}} \times 100
$$

The contribution ratio of precipitation to runoff changes $\left(C_{P}\right)$ is:

$$
C_{P}=\frac{S_{P}}{S_{R}} \times 100
$$

The contribution ratio of potential evapotranspiration to runoff changes $\left(C_{E T}\right)$ is:

$$
C_{E T}=\frac{S_{E T}}{S_{R}} \times 100
$$

The contribution ratio of snowmelt to runoff changes $\left(C_{S}\right)$ is:

$$
C_{S}=100-C_{P}-C_{E T}
$$

In the formula: the subscript $P$ indicates precipitation; $R$ indicates runoff; $E T$ indicates evapotranspiration; and $S$ indicates ice and snowmelt water.

\section{Results}

\subsection{Characteristics of climatic factors change in the Xiying River Basin}

3.1.1 The interannual variation characteristics of climatic factors. The change trend of temperature, precipitation and evapotranspiration in the Xiying River Basin was analyzed with five years as a unit (Figure 2). The results showed that the overall trend of warm and wet changes in the Xiying River Basin was related to the predecessors against Qilian Mountain. The results of the regional studies were basically similar [34-35]. From 1961 to 2017 , the temperature showed a temperature increase trend of $0.033{ }^{\circ} \mathrm{C} \cdot \mathrm{a}^{-1}$ in this basin, and the annual average anomaly temperature changed from negative to positive in 1987, which was from $0.026{ }^{\circ} \mathrm{C} \cdot \mathrm{a}^{-1}$ to $0.039{ }^{\circ} \mathrm{C} \cdot \mathrm{a}^{-1} \quad$ (Figure 2a). The precipitation showed an upward trend of $0.813 \mathrm{~mm} \cdot \mathrm{a}^{-1}$ from 1961 to 2017, and this trend became more apparent in the 21st century (Figure 2b). Combined with the changes of annual precipitation and temperature, it can be seen that the Xiying River Basin had a tendency 
toward cold and wet in 1961-1986, then the tendency changed toward warm and wet after 1987. In addition, the potential evapotranspiration showed a trend of 0.773 $\mathrm{mm} \cdot \mathrm{a}^{-1}$ from 1961 to 2017. Compared with the
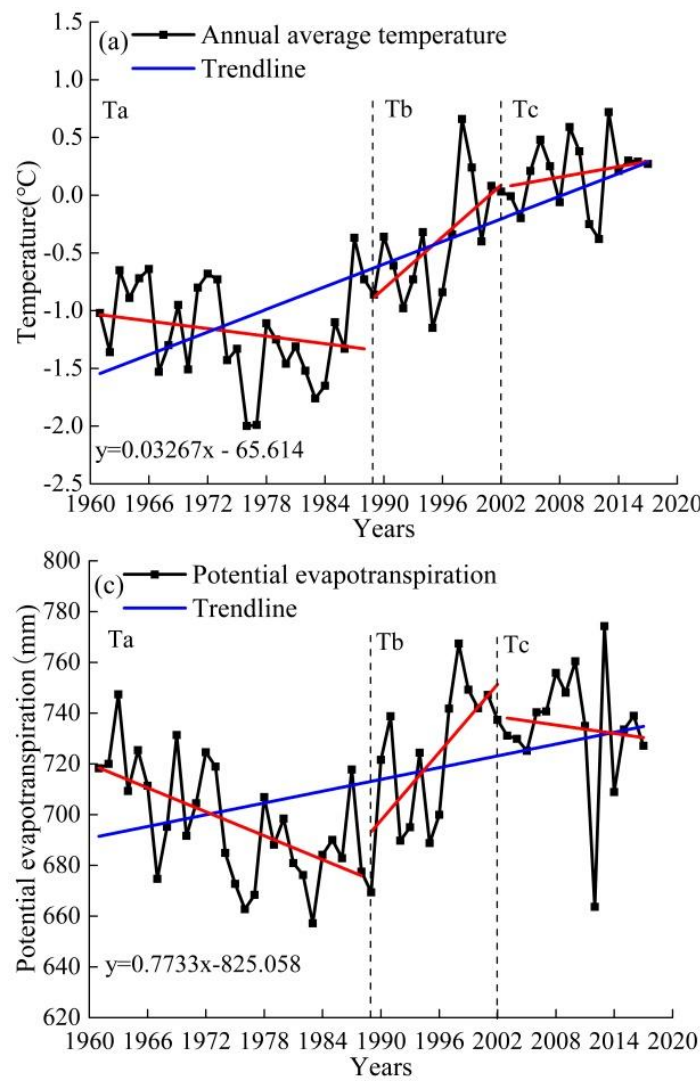

Figure 2. These Average temperature (a), precipitation (b), potential evapotranspiration (c), and Xiying River runoff (d) interannual variation. $T_{a}$ : 1961-1989 years, $T_{b}$ : 1990-2002years, $T_{c}$ : 2003-2017years; blue line: overall trend line, red line: segmentation trend line.

\subsubsection{Climatic factor mutation characteristics.} According to the mutation analysis (Figure 3a), the temperature of the Xiying River Basin in the M-K test showed an intersection point in 1996 and was tested by the significance level of $\mathrm{P}=0.05$. The UF value began to be greater than the critical value of 1.96 in 1998, indicating that the temperature began to show a more obvious trend. At the same time, from the change of the cumulative anomaly value (Figure 4a), it can be seen that the cumulative anomaly temperature reached a minimum in 1996. After that, the annual average temperature rises and the trend increases, which was same as the results verified by the Pettitt method. The results of the sudden change in precipitation (Figure $3 \mathrm{~b}$ ) indicated that UF and temperature change, the time of annual average anomalous evapotranspiration changed from negative to positive value was later and the change range of each unit was small (Figure 2c).
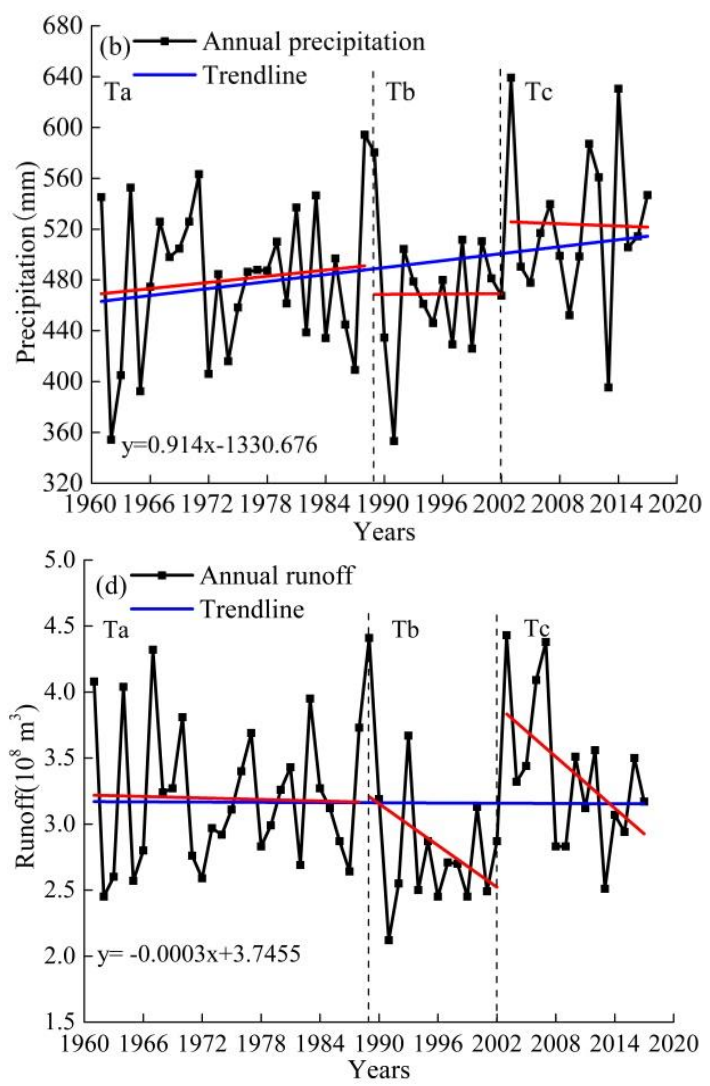

UB have multiple fluctuation intersections, but they have not passed the $\mathrm{P}=0.05$ significance level test; In the analysis of cumulative anomaly variation, the cumulative anomaly of precipitation (Figure 4b) decreased sharply after 1989 and reached a minimum in 2002, followed by an upward trend. The results verified by the Pettitt method showed that the precipitation had mutation occurred in 2002. The change of potential evapotranspiration in this basin was similar to the suddenly change in temperature. UF and UB intersected in 1996 and passed the significance level test of $\mathrm{P}=0.05$ (Figure 3c). The cumulative anomaly reached the minimum value in 1996 (Figure 4c) and the Pettitt method determined that evapotranspiration's mutation occurred in 1996. 

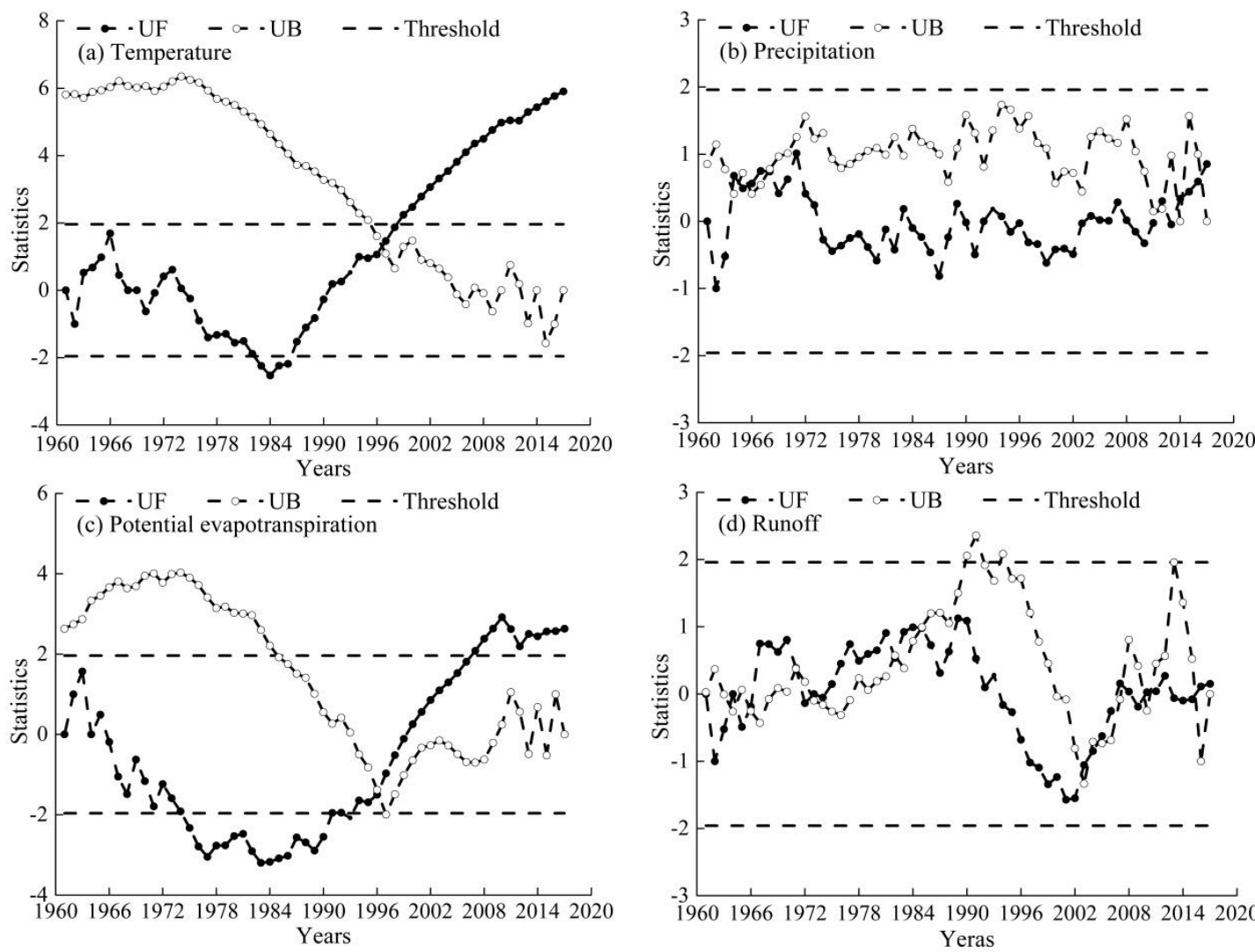

Figure 3. Annual average temperature (a), precipitation (b), potential evapotranspiration (c), and runoff sequence (d) mutation point M-K analysis of the Xiying River Basin.
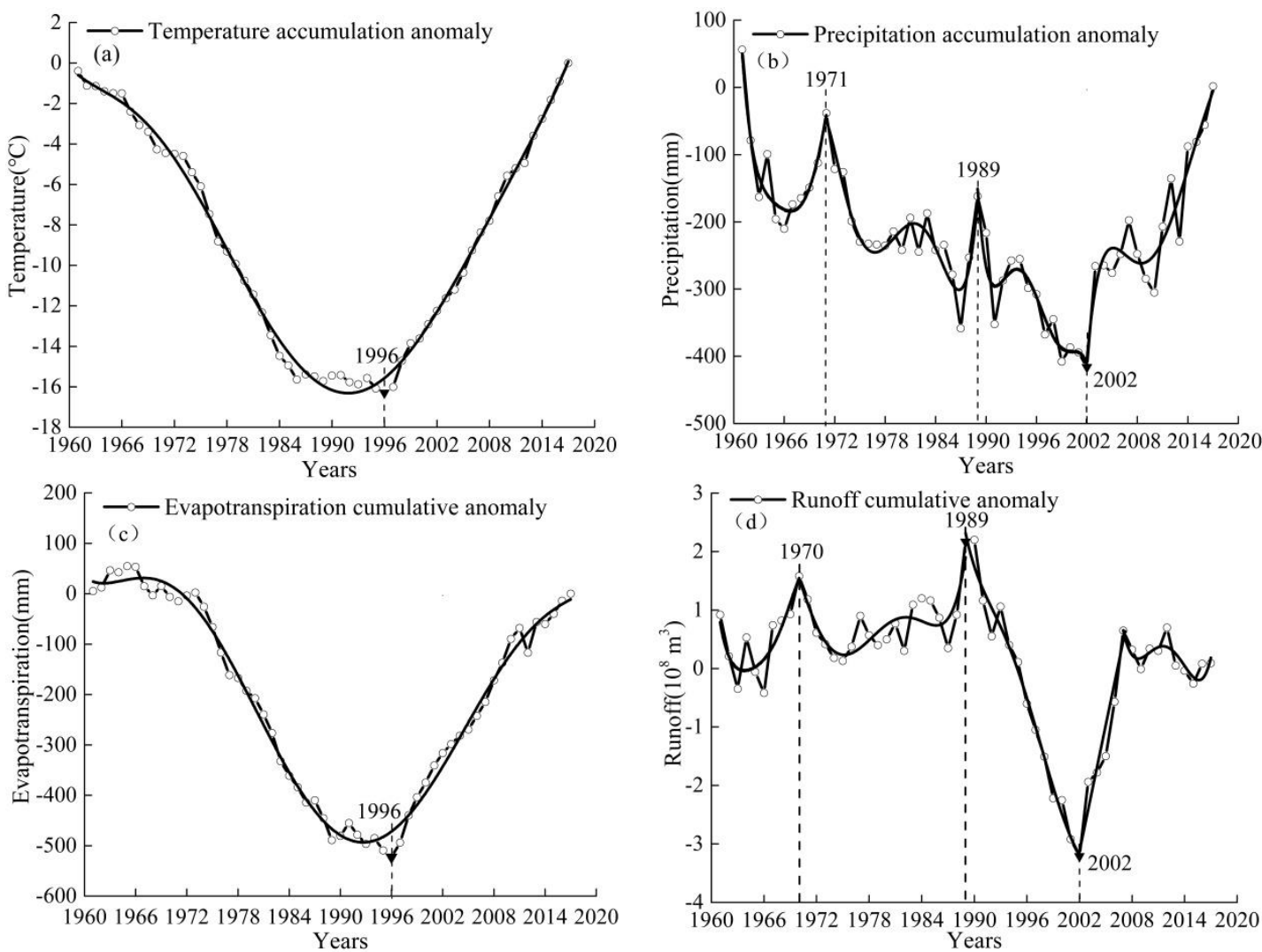

Figure 4. Annual average temperature (a), precipitation (b), potential evapotranspiration (c) and runoff (d) cumulative anomalies in the Xiying River Basin. 


\subsection{Characteristics of runoff variation in the Xiying River Basin}

3.2.1 Interannual trends. The runoff of the Xiying River showed a weak downward trend during the period from 1961 to 2017, which was similar to the previous study on the runoff of the Shiyang River Basin [36], and its rate of change was $-0.0003 \times 10^{8} \mathrm{~m} \cdot \mathrm{a}^{-1}$, but Changes in runoff in the basin have large changes in different time periods (Figure 2d). It can be seen from the five-year sliding mean of the annual runoff that the annual runoff of the Xiying River fluctuated less before the 1990s, and then the fluctuation range became larger and the lowest and highest values of annual runoff appeared. At the same time, we found that the runoff of Xiying River in 1961-2017 showed a trend of decline-rise-rise-rise-risefall combined with polynomial regression analysis.

\subsubsection{The mutation characteristics of runoff. Used} $\mathrm{M}-\mathrm{K}$ and cumulative anomaly method to analyze the runoff variation in the Xiying River Basin, it had found that there were multiple fluctuation intersections in the runoff of the M-K test, so there may be pseudo-mutation points (Figure $3 \mathrm{~d}$ ). It can be seen from the cumulative

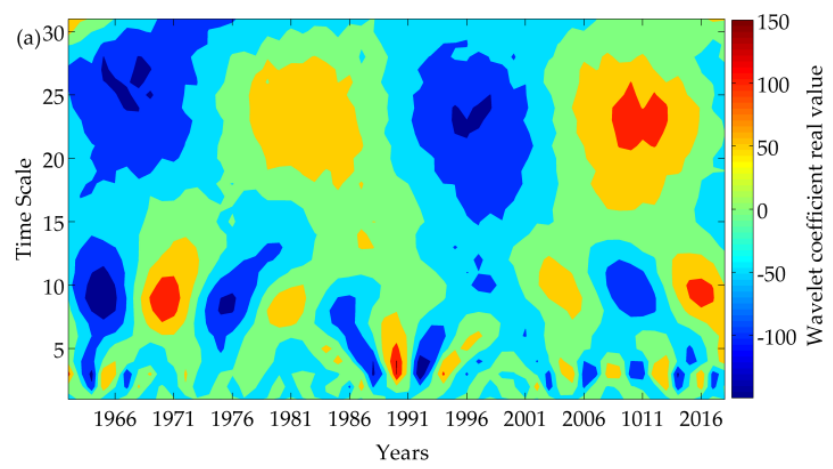

runoff anomaly map (Figure 4d) that the runoff had an inflection point in 1989 (maximum value) and 2002(minimum value), and the cumulative runoff anomaly was divided into three segments, thus showing an increase - Decline-rise trend. At the same time, the Pettitt test determined that the runoff of the Xiying River was mutated in 1989 and 2002. Combined with Figure $2 \mathrm{~d}$, the runoff of the basin showed a trend of $0.0067{ }^{\circ} \mathrm{C} \cdot \mathrm{a}^{-1}$ from 1961 to 1989 ; in $1990-2002$, there was a trend of $-0.0064{ }^{\circ} \mathrm{C} \cdot \mathrm{a}^{-1}$, and showed a trends of $0.0649{ }^{\circ} \mathrm{C} \cdot \mathrm{a}^{-1}$ in $2003-2017$. The runoff had obvious trend before and after the mutation.

3.2.3 River periodicity. In the wavelet analysis of the inter-annual variation of the runoff in the Xiying River, it was found a relatively obvious periodicity (Figure 5). According to the wavelet transform and the variance test, the Xiying River runoff showed the first main cycle change of 15 years, followed by sub-period change of 24 years and 3 years. The results were similar to the conclusions of the Shiyang River runoff cycle [37], which indicates that the Xiying River had similar runoff changes with the Shiyang River as the largest tributary of the Shiyang River source area. Their runoff changes were closely related.

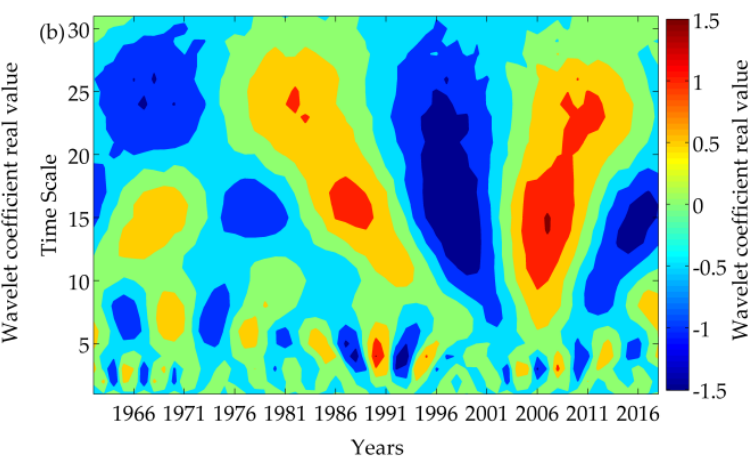

Figure 5. Precipitation (a) and runoff (b) wavelet analysis of Xiying River Basin.

\subsection{The response characteristics of runoff and climatic factor}

runoff began to become insignificant and gradually changed to a positive correlation trend. The potential evapotranspiration and runoff were significantly negatively correlated before the period from 1978 to $2005(\mathrm{P}<0.05)$, and the correlation became insignificant after this period. Combined with the analysis of the climatic factors, it can be seen that before the early $21 \mathrm{st}$ century, temperature and evapotranspiration have a greater impact on the runoff of the Xiying River, but then the temperature and potential evapotranspiration were caused by a sudden change in the climatic factors in the region. The impact of runoff was reduced. At the same time, the used wavelet analysis also found that the precipitation and runoff cycles had a good consistency (Figure 5), although the main cycle was different, the secondary cycle were 24 years and 3 years. 


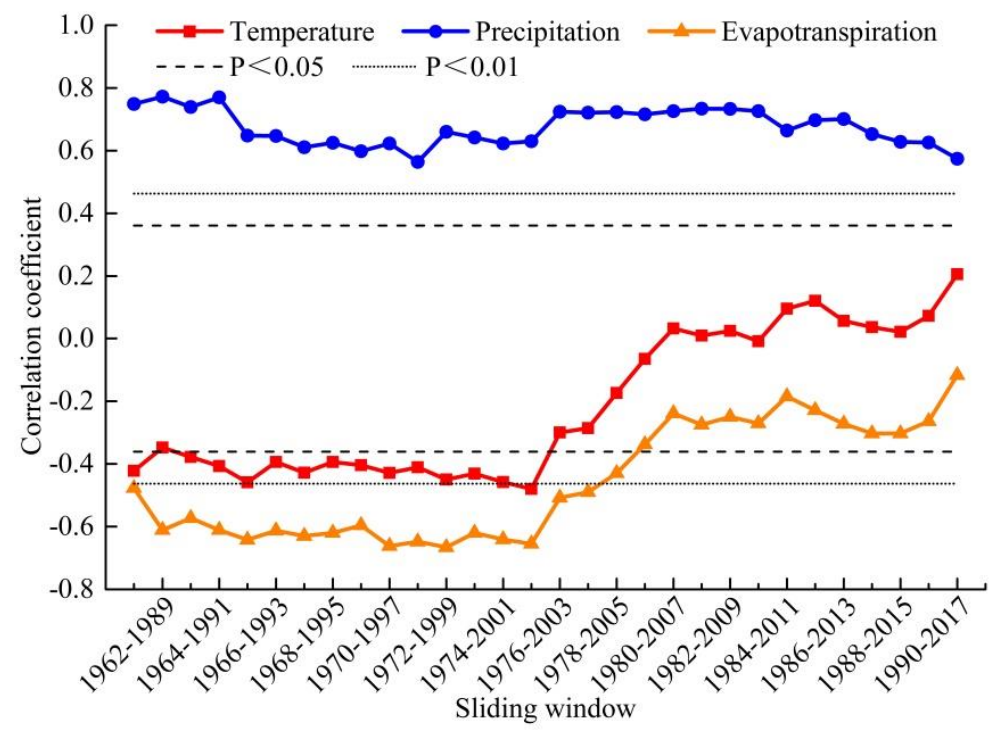

Figure 6. 28-year sliding correlation coefficient of climate factors in Xiying River Basin.

\subsection{Studied on Contribution Rate of Runoff Change in Xiying River Basin}

Xiying River Basin had a high altitude and a small population. Human activities had little impact on the ecological environment of the basin. The changed of runoff was mainly affected by natural factors such as precipitation, potential evapotranspiration and melting of snow and ice [38]. According to the previous two inflection points (1989 and 2002), the changed in the annual runoff of the Xiying River Basin was divided into three periods $\left(\mathrm{T}_{\mathrm{a}}: 1961-1989, \mathrm{~T}_{\mathrm{b}}: 1990-2002, \mathrm{~T}_{\mathrm{c}}: 2003-\right.$ 2017 ), where the $T_{a}$ period was the reference period for the change of the basin runoff. According to formula (6), the sag slope changed of runoff, precipitation and potential evapotranspiration at different time periods were calculated (Table 1).

Table 1. The slope variation of runoff meteorological and hydrological factors in the Xiying River Basin.

\begin{tabular}{|c|c|c|c|c|c|c|}
\hline \multirow{2}{*}{\multicolumn{2}{|c|}{ Period }} & \multirow{2}{*}{$\begin{array}{c}\text { The slope of } \\
\text { Cumulative runoff } \\
\left(10^{8} \mathrm{~m}^{3} \cdot \mathrm{a}^{-1}\right)\end{array}$} & \multicolumn{2}{|c|}{$\begin{array}{c}\text { The cumulative slope } \\
\text { (Compared with Ta period) }\end{array}$} & \multicolumn{2}{|c|}{$\begin{array}{c}\text { The cumulative slope } \\
\text { (Compared with Tb period) }\end{array}$} \\
\hline & & & $\begin{array}{c}\text { Slope change } \\
\left(10^{8} \mathrm{~m}^{3} \cdot \mathrm{a}^{-1}\right)\end{array}$ & $\begin{array}{c}\text { Rate of } \\
\text { change }(\%)\end{array}$ & $\begin{array}{c}\text { Slope change } \\
\left(10^{8} \mathrm{~m}^{3} \cdot \mathrm{a}^{-1}\right)\end{array}$ & $\begin{array}{c}\text { Rate of } \\
\text { change }(\%)\end{array}$ \\
\hline $\mathrm{T}_{\mathrm{a}}:$ & 1961-1989 & 3.19 & - & - & - & - \\
\hline $\mathrm{T}_{\mathrm{b}}:$ & 1990-2002 & 2.73 & -0.46 & -14.42 & - & - \\
\hline $\mathrm{T}_{\mathrm{c}}:$ & 2003-2017 & 3.28 & 0.09 & 2.82 & 0.55 & 20.15 \\
\hline \multirow{2}{*}{\multicolumn{2}{|c|}{ Period }} & \multirow{2}{*}{$\begin{array}{c}\text { The slope of } \\
\text { precipitation } \\
\left(\mathrm{mm} \cdot \mathrm{a}^{-1}\right)\end{array}$} & \multicolumn{2}{|c|}{$\begin{array}{c}\text { The cumulative slope } \\
\text { (Compared with Ta period) }\end{array}$} & \multicolumn{2}{|c|}{$\begin{array}{c}\text { The cumulative slope } \\
\text { (Compared with Tb period) }\end{array}$} \\
\hline & & & $\begin{array}{c}\begin{array}{c}\text { Slope change } \\
\left(\mathrm{mm} \cdot \mathrm{a}^{-1}\right)\end{array} \\
\end{array}$ & $\begin{array}{c}\text { Rate of } \\
\text { change }(\%)\end{array}$ & $\begin{array}{c}\begin{array}{c}\text { Slope change } \\
\left(\mathrm{mm} \cdot \mathrm{a}^{-1}\right)\end{array} \\
\end{array}$ & $\begin{array}{c}\text { Rate of } \\
\text { change }(\%)\end{array}$ \\
\hline $\mathrm{T}_{\mathrm{a}}:$ & 1961-1989 & 482.61 & - & - & - & - \\
\hline $\mathrm{T}_{\mathrm{b}}:$ & $1990-2002$ & 466.04 & -16.57 & -3.43 & - & - \\
\hline $\mathrm{T}_{\mathrm{c}}:$ & 2003-2017 & 516.27 & 33.66 & 6.97 & 50.23 & 10.78 \\
\hline \multirow{2}{*}{\multicolumn{2}{|c|}{ Period }} & $\begin{array}{c}\text { The slope of } \\
\text { potential }\end{array}$ & \multicolumn{2}{|c|}{$\begin{array}{c}\text { The cumulative slope } \\
\text { (Compared with Ta period) }\end{array}$} & \multicolumn{2}{|c|}{$\begin{array}{c}\text { The cumulative slope } \\
\text { (Compared with } \mathrm{Tb} \text { period) }\end{array}$} \\
\hline & & $\begin{array}{c}\text { evapotranspiration } \\
\left(\mathrm{mm} \cdot \mathrm{a}^{-1}\right)\end{array}$ & $\begin{array}{c}\begin{array}{c}\text { Slope change } \\
\left(\mathrm{mm} \cdot \mathrm{a}^{-1}\right)\end{array} \\
\end{array}$ & $\begin{array}{c}\text { Rate of } \\
\text { change }(\%)\end{array}$ & $\begin{array}{c}\text { Slope change } \\
\left(\mathrm{mm} \cdot \mathrm{a}^{-1}\right)\end{array}$ & $\begin{array}{c}\text { Rate of } \\
\text { change }(\%)\end{array}$ \\
\hline $\mathrm{T}_{\mathrm{a}}:$ & 1961-1989 & 716.56 & - & - & - & - \\
\hline $\mathrm{T}_{\mathrm{b}}:$ & $1990-2002$ & 705.51 & -11.05 & -1.54 & - & - \\
\hline $\mathrm{T}_{\mathrm{c}}:$ & 2003-2017 & 735.33 & 18.77 & 2.62 & 29.82 & 4.23 \\
\hline
\end{tabular}

It can be seen from Table 1 that the cumulative runoff slopes in the three periods of $\mathrm{T}_{\mathrm{a}}, \mathrm{T}_{\mathrm{b}}$ and $\mathrm{T}_{\mathrm{c}}$ were $3.19 \times 10^{8} \mathrm{~m}^{3} \cdot \mathrm{a}^{-1}, 2.73 \times 10^{8} \mathrm{~m}^{3} \cdot \mathrm{a}^{-1}$ and $3.28 \times 10^{8} \mathrm{~m}^{3} \cdot \mathrm{a}^{-1}$, respectively and experienced the process of falling and rising again. Compared with $\mathrm{T}_{\mathrm{a}}$, the cumulative runoff slope of the $T_{b}$ period shows a decreasing change of -
$0.46 \times 10^{8} \mathrm{~m}^{3} \cdot \mathrm{a}^{-1}$, and the change ratio was $14.42 \%$. The slope of cumulative amount of precipitation and potential evapotranspiration in the same period was $-16.27 \mathrm{~mm}^{\cdot} \mathrm{a}^{-}$ 1 and $-11.05 \mathrm{~mm} \cdot \mathrm{a}^{-1}$, downward trend was $3.43 \%$ and $1.54 \%$, respectively. According to formula (7) and formula (8), the influence of precipitation and potential 
evapotranspiration on runoff variation was calculated. Compared with $\mathrm{T}_{\mathrm{a}}$ period, the contribution rate of precipitation and potential evapotranspiration to runoff variation in $T_{b}$ period was $23.79 \%$ and $10.68 \%$ respectively. Without considering the influence of temperature and other factors, according to formula (9), the contribution rate of snow and ice melt water to the runoff change in the $T_{b}$ period was $65.53 \%$.

Compared the $T_{c}$ period with the $T_{b}$ period, it can be found that the cumulative runoff slope change shows an increase of $0.55 \times 10^{8} \mathrm{~m}^{3} \cdot \mathrm{a}^{-1}$ with a change rate of $20.15 \%$. The cumulative precipitation and evapotranspiration slope at the same time show $50.23 \mathrm{~mm} \cdot \mathrm{a}^{-1}$ and 29.82 $\mathrm{mm} \cdot \mathrm{a}^{-1}$, respectively. The ratio was $10.78 \%$ and $4.23 \%$, respectively. Compared with the $\mathrm{T}_{\mathrm{b}}$ period, the contribution rate of precipitation and evapotranspiration to the runoff change in the $\mathrm{T}_{\mathrm{c}}$ period was $53.5 \%$ and $20.99 \%$, respectively, and the contribution rate of the snow melt water to the runoff change was $25.52 \%$.

Comparing the three periods, it can be seen that the contribution rate of precipitation to the runoff variation of Xiying River increased from $23.79 \%$ in the $\mathrm{T}_{\mathrm{b}}$ period to $53.5 \%$ in the $\mathrm{T}_{\mathrm{c}}$ period, an increase of $29.71 \%$. The contribution of potential evapotranspiration to the change of runoff in the same period, the rate increased from $10.68 \%$ to $20.99 \%$, an increase of $10.31 \%$. The contribution rate of ice and snow melt water to runoff change decreased from $65.53 \%$ to $25.52 \%$, a decrease of $40.01 \%$. In the three research periods, the contribution rate of precipitation and potential evapotranspiration to the runoff change in the Xiying River Basin was increase, with the largest increased in precipitation, while the contribution rate of ice and snow melt water to the change of runoff. The downward trend was similar to the results of previous studies on the snow cover area in the Qilian Shandong section [39-40]. Based on the above analysis, it can be seen that since 1961, the influence of precipitation, potential evapotranspiration and snowmelting water on the runoff variation of the Xiying River Basin had changed greatly. The influence of precipitation on runoff had gradually increased and became the main factor of influence.

\section{Discussion}

\subsection{Response analysis of runoff changes in Xiying River to climatic factors}

In this paper, we analyzed the climate and runoff characteristics of the Xiying River Basin from 1961 to 2017. Although the temperature, precipitation and evapotranspiration in the basin show an increasing trend, the climate factors in the Xiying River Basin were related to runoff sliding. In the results, the correlation between temperature, precipitation, evapotranspiration and runoff during this period has a large difference (Figure 6).

Throughout the study period, the runoff and precipitation in this area maintained a significant positive correlation. At the same time, combined with the analysis of watershed precipitation and runoff, it can be seen that the runoff variation in the Xiying River Basin was closely related to the precipitation. Such results have also been confirmed in previous studies of the basin [41]. In addition, many studies indicate that river runoff was highly dependent on precipitation in small watersheds [42-44]. As the tributary of the source of the Shiyang River, the Xiying River has a small drainage area, so the runoff was significantly affected by precipitation.

The correlation between temperature and potential evapotranspiration and runoff showed significant changes in the early 21 st century, both from significant negative correlation to insignificant (Figure 6). Which indicated that the runoff of the Xiying River was less affected by temperature and evapotranspiration, which may be due to a decrease in the rate of temperature rise and a decrease in potential evapotranspiration (Figure 2a and Figure 2c). This increased difficulty in converting glaciers and snow into surface runoff [39-40]. In addition, previous studies have shown that the temperature of glacial snowmelt may lead to an increase in seasonal runoff in the short term, but it would lead to the reduction of subsequent runoff in the medium and long term [45]. Therefore, after half a century of climate warming and a sudden change in climate in the early $21 \mathrm{st}$ century, the negative correlation between runoff in Xiying River Basin and temperature and potential evapotranspiration was greatly reduced.

\subsection{Analysis of the variation of the runoff rate of the Xiying River}

In this paper, the study on the change of the runoff contribution rate in the Xiying River Basin showed that the main contribution rate of the runoff in this region was changed from ice and snow melt to precipitation in the $T_{c}$ period (2003-2017) compared with the $T_{b}$ period (19902002). The precipitation contribution rate of in the Xiying River Basin increased significantly during the $T_{c}$ period, and the contribution rate of evapotranspiration also increased, but the contribution rate of ice and snow melted water decreased significantly. This change may be related to sudden changes in temperature, precipitation, and potential evapotranspiration. Between 1990 and 2002, precipitation in this area decreased significantly, while temperature and evapotranspiration increased significantly during this period (Figure 2), so glaciers and snow were favored to be converted into ice and snow melted under the influence of temperature and other factors [46], which made it more important to contribute to the change of runoff. Analyzed glaciers and runoffs in the Nalin River Basin in Central Asia found that snow and ice melt water was significantly affected by temperature changes. Since global warming, the shrinkage of large glaciers and glaciers had accelerated, and snow and ice melt water had become an important source of runoff [47]. In 2002, the precipitation and runoff in the Xiying River Basin showed a sudden change. After 2002, the precipitation became the main factor affecting the change of runoff. Using the CMIP5 model to simulate and analyzed the uncertain effects of climate change on rivers, it had found that the change of 
precipitation had more obvious effect on runoff than temperature. In the RCP4.5 scenario, the annual average runoff would decrease from $13.3 \%$ to $27.7 \%$ [48]. In addition, when analyzed the change of runoff in the ADR river basin in Central Asia, it was also found that the dominant factor causing the decline of runoff in the basin was precipitation rather than temperature. The decrease in precipitation reduces the runoff by $15.5 \%$. The increase in temperature only increases the runoff by $0.2 \%$ [49].

\section{Conclusions}

In 1961-2017, the temperature in the Xiying River basin showed a trend of $0.033{ }^{\circ} \mathrm{C} \cdot \mathrm{a}^{-1}$, and the mutation occurred in 1996; the precipitation showed a trend of $0.915 \mathrm{~mm} \cdot \mathrm{a}^{-1}$, and the mutation occurred in 2002 ; the evapotranspiration showed a change trend of 0.336 $\mathrm{mm} \cdot \mathrm{a}^{-1}$ occurred in 1996 . The runoff in the Xiying River Basin showed a weak downward trend of $-0.0003 \times 10^{8}$ $\mathrm{m}^{3} \cdot \mathrm{a}^{-1}$, and it was mutated in 1989 and 2002. The cumulative anomaly trend before and after the mutation changed significantly. At the same time, the runoff of the basin presents the first main cycle of 15 years and the secondary cycle of 24 years and 3 years.

In 1961-2017, precipitation and runoff in the Xiying River Basin have remained extremely positively correlated. The correlation between annual average temperature and runoff has changed from significant negative correlation to insignificant after 1975-2002. The potential evapotranspiration and runoff also changed from a significant negative correlation to insignificant after the period from 1978 to 2005 .

Compared with the $T_{a}$ period, the cumulative runoff slope showed a downward trend in the $T_{b}$ period, and the contribution rates of precipitation, evapotranspiration and snow-melt water to runoff were $23.79 \%, 10.68 \%$ and $65.53 \%$, respectively. The contribution rate of runoff variation during this period was mainly snow and ice melt water; while the cumulative runoff slope was still decreasing compared with $\mathrm{T}_{\mathrm{b}}$ in $\mathrm{T}_{\mathrm{c}}$ period, the contribution rate of precipitation, evapotranspiration and snow-melt water to runoff change was $53.5 \%, 20.99 \%$ and $25.52 \%$, and the contribution rate of runoff change during this period was mainly precipitation. Compared with the $T_{c}$ period and the $T_{b}$ period, the contribution rate of precipitation to runoff change was increased by $29.71 \%$, the evapotranspiration increased by $10.31 \%$, and the ice and snow melt water decreased by $40.01 \%$.

\section{References}

1. Cui, X., Guo, X., Wang, Y., Wang, X., Zhu, W., Shi, J., Lin, C., Gao, X. (2019) Application of remote sensing to water environmental processes under a changing climate. J. Hydrol, 574: 892-902.

2. Donat, M.G., Lowry, A.L., Alexander, L.V., O'Gorman, P. A., Maher, N. (2016) More extreme precipitation in the world's dry and wet regions. Nat Clim Change, 6: 508-513.
3. Huntington, T.G. (2016) Evidence for intensification of the global water cycle: review and synthesis. J. Hydrol, 319: 83-95.

4. Zhong, C.Z., Yong, L., Jian, B.H. (2018) Review of IPCC 30 years (1988-2018). Progress in Climate Change Research, 14: 108-114.

5. Hartmann, D.L., Tank, A., Rusticucci, M. (2013) IPCC fifth assessment report, climate change 2013: The physical science basis. IPCC AR5, 5: 31-39.

6. Arnell, N.W. (1999) Climate change and global water resources. Global Environ Change, 9: S31-S49.

7. Arora, V.K., Boer, G.J. (2001) Effects of simulated climate change on the hydrology of major river basins. J. Geophys Res-Atmos, 106: 3335-3348.

8. Sorribas, M.V., Paiva, R.C., Melack, J.M., Bravo, J.M., Jones, C., Carvalho, L., Beighley, E., Forsberg, B., Costa, M. H. (2016) Projections of climate change effects on discharge and inundation in the Amazon basin. J. Climatic change, 136: 555-570.

9. Chen, J., P. Brissette, F., Poulin, A., Leconte, R. (2011) Overall uncertainty study of the hydrological impacts of climate change for a canadian watershed. Water Resour Res, 47: W12509.

10. Radchenko, I., Dernedde, Y., Mannig, B., Frede, H.G., Breuer, L. (2017) Climate change impacts on runoff in the Ferghana Valley (Central Asia). Water Resour+, 44: 707-730.

11. Langerwisch, F., Rost, S., Gerten, D., Poulter, B., Rammig, A., Cramer, W. (2013) Potential effects of climate change on inundation patterns in the Amazon Basin. Hydrol Earth Syst Sci, 17: 22472262.

12. Deng, H., Chen, Y. (2017) Influences of recent climate change and human activities on water storage variations in Central Asia. J. Hydrol, 544: 46-57.

13. Pathak, P., Kalra, A., Ahmad, S. (2017) Temperature and precipitation changes in the Midwestern United States: implications for water management. Int. J. Water Resour D, 33: 1003-1019.

14. Milliman, J.D., Farnsworth, K.L., Jones, P.D., Xu, K H., Smith, L.C. (2008) Climatic and anthropogenic factors affecting river discharge to the global ocean, 1951-2000. Global Planet Change, 62: 187-194.

15. Hasan, E., Tarhule, A., Kirstetter, P. E., Clark III, R., Hong, Y. (2018) Runoff sensitivity to climate change in the Nile River Basin. J. Hydrol, 561: 312321.

16. Coles, A.E., McConkey, B. G., McDonnell, J.J. (2017) Climate change impacts on hillslope runoff on the northern Great Plains, 1962-2013. J. Hydrol, 550: 538-548.

17. Bliss, A., Hock, R., Radić, V. (2014) Global response of glacier runoff to twenty - first century climate change. J. Geophys Res-Earth, 119: 717-730.

18. Gan, R., Luo, Y., Zuo, Q., Sun, L. (2015) Effects of projected climate change on the glacier and runoff 
generation in the Naryn River Basin, Central Asia. J. Hydrol, 523: 240-251.

19. Qin, J., Liu, Y., Chang, Y., Liu, S., Pu, H., Zhou, J. (2016) Regional runoff variation and its response to climate change and human activities in Northwest China. J. Environ Earth Sci, 75: 1366.

20. Pepin, N., Bradley, R.S., Diaz, H.F., Baraer, M., Caceres, E.B., Forsythe, N., Fowler, H., Greenwood, G., Hashmi, M.Z., Liu, X.D., Miller, J.R., Ning, L., Ohmura, A., Palazzi, E., Rangwala, I., Schöner, W., Severskiy, I., Shahgedanova , M., Wang, M.B., Williamson, S.N., Yang, D.Q. (2015) Elevationdependent warming in mountain regions of the world. J. Nat Clim Change, 5: 424.

21. Zhou, D.G., Huang, R.H. (2012) Response of water budget to recent climatic changes in the source region of the Yellow River. J. Chinese Science Bulletin, 57: 2155-2162.

22. Liu, X., Chen, B. (2000) Climatic warming in the Tibetan Plateau during recent decades. Int J Climatol, 20: $1729-1742$.

23. Wang, Q.J., Chun, X.H., Xu, H.M., Zhan, F.D. (2019) Roadmap of the Ecological Civilization Demonstration Zone Construction in the Gansu Qilian Mountain. Environmental Protection, 47: 3336.

24. Zong, L., Qi, F., Wang, Q.J., Song, Y., Hong, L., Yong, L. (2016) The influence from the shrinking cryosphere and strengthening evopotranspiration on hydrologic process in a cold basin, Qilian Mountains. Global Planet Change, 144: 119-128.

25. Jun, J.Z., Li L., Pei, J.S., Lan, Y.W., Wei, W., Hai, M.L. (2015) Response of runoff to the climate and land use pattern changes in Shiyang River Basin. Acta Ecologica Sinica, 35: 3788-3796.

26. Ling, L.Z., Xue, X.Z. (2011) Analysis of the Characteristics of Temperature and Precipitation in the Heihe River Basin in the Past 50 Years. J. Resources Science, 33: 1877-1882.

27. Li, Y.C., Chao, L.Y., Lian, W.N., You, W.Q., Lin, L.Y. (2017) Mountain runoff change and its climatic factors in the upper reaches of the Shule River from 1958 to 2015. J. Scientia Geographiva Sinica, 37: 1894-1899.

28. Ji, W.S., Xia, Y.Y., Ming, Y., Kun, Z.X. (2012) Analysis of Contribution Rate of Precipitation and Human Activities to Runoff Changes in Huangfuchuan Basin: Proposal and Application of Comparison Method of Cumulative Slope Change Rate. J. Acta Geographica Sinica, 67: 388-397.

29. Xia, Z.Y., Hong, Y.R., Hao, X., Lan, D., Zhu, H.H., Xi, L.X. (2019) Response of runoff changes to climate change and human activities in the Xilin River Basin. J. Arid Zone Research, 36: 67-76.

30. Mann, H.B. (1945) Nonparametric test against trend. Econometrica, 13: 245-259.

31. Xing, L., Huang, L., Chi, G., Yang, L., Li, C., Hou, X. (2018) A dynamic study of a karst spring based on wavelet analysis and the Mann-Kendall Trend Test. Water-Sui, 10: 698.

32. Jian, H.X. (2014) Metrology geography. Higher Education Press: Beijing, China.

33. Mallakpour, I., Villarini, G. (2016) A simulation study to examine the sensitivity of the Pettitt test to detect abrupt changes in mean. J. Hydrolog Sci, 61: 245-254.

34. Xiujing, M., Shifeng, Z., Yongyong, Z. (2012) The temporal and spatial change of temperature and precipitation in Hexi Corridor in recent 57 years. Acta Geographica Sinica, 67: 1482-1492.

35. Yong, C.L., Er, S.K., Ji, S.Z., Xin, L.H. (2002) Relationship between ENSO circle and air temperature precipitation and runoff in the Qilian mountain region in the past 50 years. Advances in Water Science, 13: 141-145.

36. Wen, X.W., Zheng, H.D., Jian, W.W. (2012) Impact of Climate Change on Runoff of Shiyang River in the Qilian Mountains. Journal of Glaciology and Georyology, 34: 469-477.

37. Xiao, X.Z., Yu, Z., Jie, X.H., Jun, Z.J. (2014) Analysis on the characteristics of the runoff variation and its influencing factors in the three inland river basins of the Hexi Corridor. J. Journal of Arid Land Resources and Environment, 28: 66-72.

38. Jia, F.L. (2018) Isotope Runoff Segmentation of the Xiyin River basin in the Lenglongling of the Qilian Mountains. Master's degree, Northwest Normal University, Lanzhou, 2018.

39. Ying, H.L., Dong, S.L., Jie, Z.C., Ming, G.A. (2011) Snow cover area change and its regional climate response in the Shandong section of Qilian. Journal of Arid Land Resources and Environment, 25: 109112.

40. Bing, L.P., Qing, L.Z., Hui, Z. (2019) Temporal and Spatial Variation Characteristics of Snow Covered Area in Qilian Mountains from 2001 to 2017. J. Arid Land Geo, 42: 56-66.

41. Liu, M.C., Li, L.P., Shi, Z.J., Qing, S.J. (2013) Distribution characteristics of runoff in Shiyang River basin and its responses to climate change-The case study of Xiying River. J. Agricul. Res. Arid Areas, 31: 193-198.

42. Dahal, N., Shrestha, U., Tuitui, A., Ojha, H. (2019) Temporal changes in precipitation and temperature and their implications on the streamflow of Rosi River, Central Nepal. Climate, 7: 3.

43. Gautam, M.R., Acharya, K. (2012) Streamflow trends in Nepal. Hydrol. J. Sci, 57: 344-357.

44. Sharma, R.H., Shakya, N.M. (2006) Hydrological changes and its impact on water resources of Bagmati watershed, Nepal. J. Hydrol, 327: 315-322.

45. Reyer, C. P., Otto, I. M., Adams, S., Albrecht, T., Baarsch, F., Cartsburg, M., Coumou, D., Eden, A., Ludi, E., Marcus, R., Mengel, M., Mosello, B., Robinson, A., Schleussner, C.F., Serdeczny, O., Stagl J. (2017) Climate change impacts in Central 
Asia and their implications for development. Reg Environ Change, 17: 1639-1650.

46. Olsson, O., Gassmann, M., Wegerich, K., Bauer, M. (2010) Identification of the effective water availability from streamflows in the Zerafshan river basin, Central Asia. J. Hydrol, 390: 190-197.

47. Gan, R., Luo, Y., Zuo, Q., Sun, L. (2015) Effects of projected climate change on the glacier and runoff generation in the Naryn River Basin, Central Asia. J. Hydrol, 523: 240-251.

48. Chang, J., Zhang, H., Wang, Y., Zhang, L. (2017) Impact of climate change on runoff and uncertainty analysis. J. Nat Hazards, 88: 1113-1131.

49. Panyushkina, I.P., Meko, D.M., Macklin, M.G., Toonen, W.H.J., Mukhamadiev, N.S., Konovalov, V.G., Ashikbaev, N.Z., Sagitov, A. O. (2018) Runoff variations in Lake Balkhash Basin, Central Asia, 1779-2015, inferred from tree rings. Clim Dynam, 51: 3161-3177. 